\title{
375. 黒化度補償フィルタ「ブーメラン」の使用経験
}

\section{Experience of $\mathrm{X}$-ray compensating filter [Boomerang]}

五所川原市立西北中央病院

○船 水 憲一 古川勝 文

(Kenichi Funamizu)
中央放射線 部

成 田 勝 則‥石田 晃

(Katunori Narita) (Akira Ishida)

【目的】オクトストップ社の黒 化度補償フィルタ「ブーメラ ン」の基本的特性と臨床一の 適応について検討した。

【方法】1.プーメランの密度、 CTのスライスプロフィール による内部の均一性、X線撮 影による濃度むらを調べた。 2.X線エネルギーの変化に対 する線減弱係数をブーメラン と他の物質について比較した。 まずFig.1のような単一エネ ルギーの変化に対するアクリ ル樹脂のC T值のグラフを作 り、アクリル樹脂の測定 C T 值より、スキャン時の実効工 ネルギーと水の線減弱係数を 求める。これらの值とブーメ ランの測定 CT值から、線減 弱係数を求め、表から求めた他 の物質の線減弱係数と比較した。

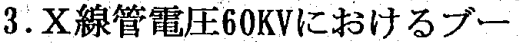
メランと水のX線透過率を比較 した。4.ブーメラン中心部断面 の形状と透過率について検討し た。5.臨床への適応。

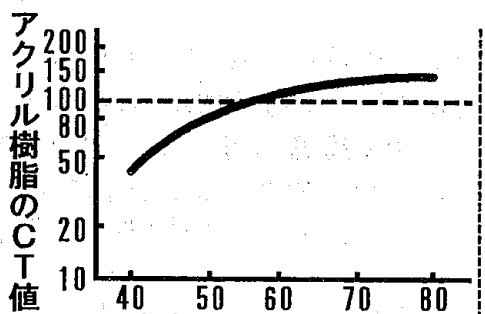

Fig 1 実効工ネルギー(K日v)

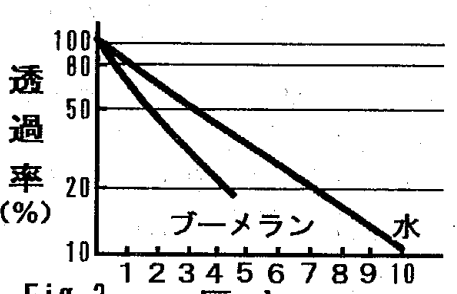

Fig. 3

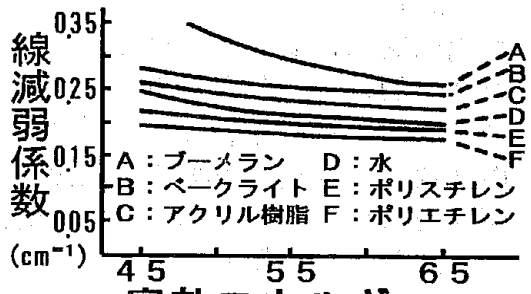

Fig. 2

【結果および考察】1.重量 $935 \mathrm{~g} 、$ 体積 $880 \mathrm{~cm}^{3} 、$ 従って密度は、 $1.06 \mathrm{~g} / \mathrm{cm}^{3}$ となった。内部の 均一性および濃度むらは問題がなかった。2。 実効エネルギーの変化による線減弱係数は、 ブーメランが、他の物質よりも高い值を取り、 エネルギーが低くなるにしたがってその差が 広がる傾向を示した(Fig.2)。つまり、黒化 度補償の必要部位に適応する管電圧範囲にお いて補償効果が高いと考えられた。3.ブーメ ランの最低透過率は、18\%であり、水 $7.3 \mathrm{~cm}$ 厚に相当した(Fig : 3)。4. 中心部断面の透過 率30\%以下の領域が高吸収部と考えられた F ig.4）。【まとめ】ブーメランの広い適用範 囲、十分な補償効果、ポータブ ルでも使用できる手軽さが確認 できた。使用上は、被写体とブ ーメランの形状の一致が、即ち 濃度補償効果とはならないこと に注意しなければならない。

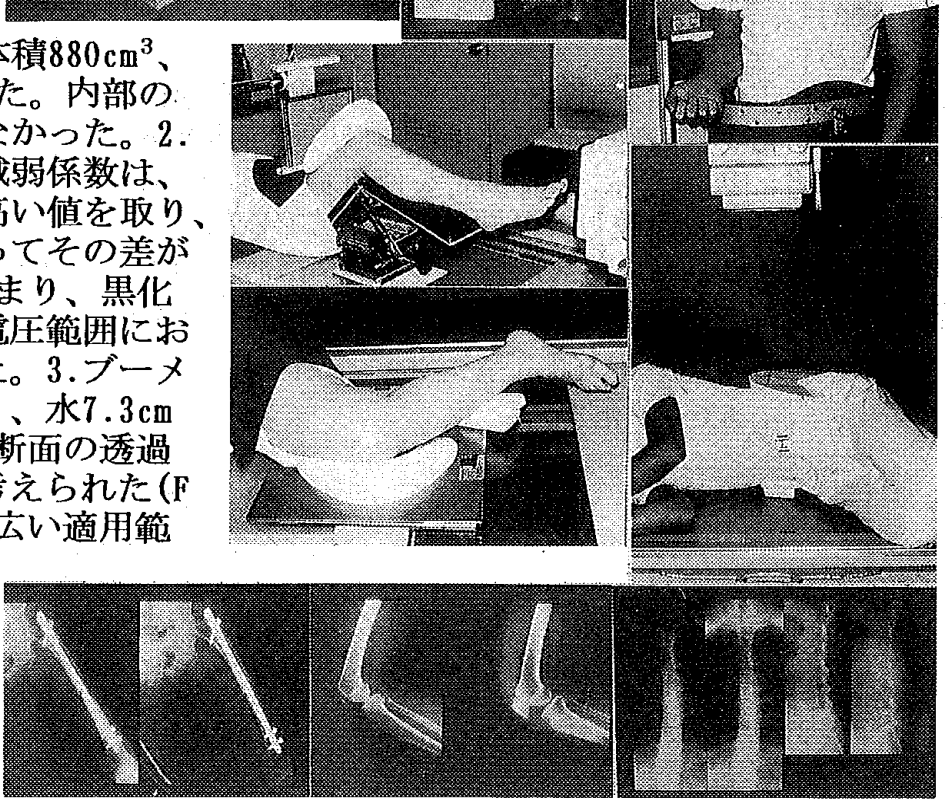

